\title{
The effect of antioxidants administration on the response rate in patients with alopecia areata
}

\author{
Ashwaq N. AL-jaff \\ College of Dentistry, University of Sulaimany
}

$\frac{\text { Received: } \quad \text { Accepted }}{1 \cdot r . r \ldots \wedge}$

\begin{abstract}
Alopecia areata $(A A)$ is autoimmune, nonscaring, multifocal disorder of hair growth characterized by circular bald areas which occur on any hair bearing site of the body. The exact cause of AA remain unknown, but the most widely accepted hypothesis suggests a T-cell mediated autoimmune activation and subsequent oxidative stress and shortage of cellular antioxidant defense to most likely occur in genetically predisposed individuals. Our previous study showed a significant contribution of oxidative stress in the pathogenesis of AA and the beneficial role of nutrient antioxidant in the modulation of the clinical picture of the disease. In this context, the present study was conducted to correlate between the duration of the attack of $A A$ and their response rate to antioxidant vitamins. In this study, ,thirty patients with AA, with a duration of disease ranged from $r \cdot$ days- $>$ Ayears were allocated into $r$ group according to the duration of attack: group ' (less than one year), group $r(1-r y e a r)$, and group $r$ (more than $r$ year).All groups received treatment schedule including a combination of antioxidants [vitamin $A$ tablet $(0 \cdots$ I.U/day), vitamin $\mathrm{E}$ tablet $(1 \cdots \mathrm{mg} / \mathrm{day})$ and vitamin $\mathrm{C}$ tablet $(0 \cdots \mathrm{mg} / \mathrm{day})]$ continued for two months. Heparinized venous blood samples were collected from patient before treatment and at one and two months after treatment. Fresh blood sample were used for malondialdehyde (MDA) and glutathione (GSH) measurement in lymphocytes and erythrocytes. The susceptibility of lymphocytes and erythrocytes to oxidative stress was measured by in-vitro challenge with $v_{.} \circ \% \mathrm{H}_{r} \mathrm{O}_{r}$. The result of this study revealed that there is no significant difference in the response rate between the study groups to antioxidant treatment, so the use of antioxidant by patients with AA improve rate of hair growth regardless the duration of attack.
\end{abstract}

الخلاصة داء الحاصة البقعية من الأمر اض المناعية والتي تمتاز بوجود بقع دائرية صلعاء على فروة الر أس و التي ممكن أن تحدث في أي مكان على الجسم إلى وقتنا هذا لا يعرف سبب حقيقي مثبت لهذا المرض،لكن من أكثر النضريات قبو لا هي التي تقترح تنشيط الخلايا المناعية وما ينتج عنها من إجهاد تأكسدي و قصر في دفاعات الخلايا ضد الإجهاد التاكسدي. أظهرت دراستنا السابقة دور ملحوظ لجذور الأوكسجين الحرة في أمر اضية الحاصة البقعية والدور الفعال لمانعات الأكسدة. في تحوير الصورة السريرية للمرض.في محتوى الدراسة الحالية تم الربط بين مدة الإصابة بمرض الحاصة البقعية ومدى

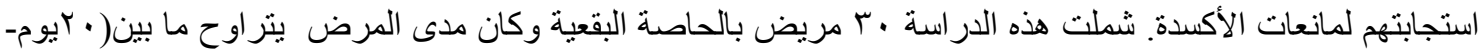
1 (عام).تم تقسيم المرضى إلى ثلاثة مجاميع حسب مدى المرض:المجموعة الأولى مدى المرض اقل من عام،المجموعة

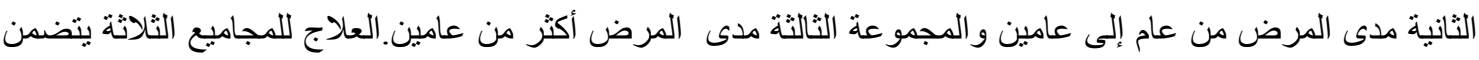




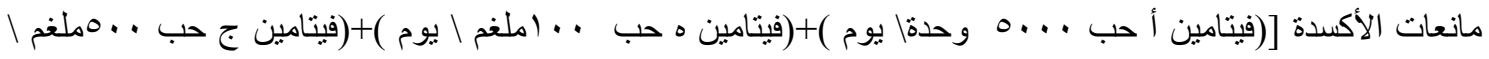

$$
\begin{aligned}
& \text { يوم)] لمدة شهرين فقط. تم سحب عينات الدم من المرضى قبل العلاج و بعد شهر و شهرين من العلاج بمانعات } \\
& \text { الأكسدةونم قياس مستويات المالوندايدهايد والكلوتاثايون في الخلايا اللمفاوية وكريات الدم الحمر اء لعينات ما خوذة في } \\
& \text { نفس اليوم .كما وتم قياس حساسية الخلايا اللمفاوية وكريات الدم الحمر اء للتأكسد باستخدام بيروكسيد الهيدروجين المحدث } \\
& \text { في المختبر. أظهرت نتائج هذه الدراسة اختلاف غير ملحوظ في سرعة استجابة المجاميع الثلاثة لمانعات الأكسدة ،لذا } \\
& \text { فان استخدام مانعات الأكسدة لمرضى داء الثعلبة الجزئي يحسن من سرعة نمو الثعر بغض النظر عن مدة الإصسابة } \\
& \text { بالمرض. }
\end{aligned}
$$

A lopecia areata (AA) is a form of hair loss from areas of the body, usually from the scalp. Because it causes bald spots on the head, especially in the first stages, it is some times called spot baldness. In 1-r\% of cases, the condition can spread to the entire scalp (Alopecia totalis) or to the entire epidermis (Alopecia universalis). AA affect $1-r \%$ of the population. ${ }^{1-0}$

The autoimmune pathophysiology of the disease involves mistake treating of body's hair follicles as foreign tissue and suppressing or stopping hair growth. There is some evidence that $\mathrm{T}$ cell lymphocytes cluster around these follicles, causing inflammation and subsequent hair loss. ${ }^{r},{ }^{r-q}$ As with most autoimmune diseases, AA is associated with increased risk of developing other autoimmune disease, especially systemic lupus erythromatosus (SLE).

In about $0 . \%$ of patients with $\mathrm{AA}$, hair will regrow in one year without any treatment, however, even if the affected region is small, it is reasonable to observe the progression of the illness as the problem often spontaneously regresses and the hair grows back.'. On the other hand, in cases where there is severe hair loss, there has been limited success treating AA with clobetasol or fluocinonide, steroid injections or cream $^{(1)}$.Steroid injections are commonly used in sites where there are small area of hair loss on the head or especially where eyebrow hair has been lost $1 v-19$ Some other medications used are minoxidil, irritants (anthralin or topical coal tar), and topical immunotherapy cyclosporine ,each of which are sometimes used in different combinations." Some non-clinical treatment results have been observed through the ingestion of natural anti-inflammatory agents, particularly blackcurrant and borage oils in caplet form and zinc supplement tablets. ${ }^{r-r r}$

In the past few years, several studies have presented several lines of evidences for the involvement of reactive oxygen species (ROS) as damaging radicals in the pathogenesis of

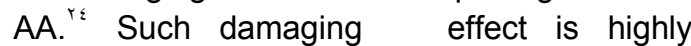
controlled by antioxidants $^{r^{\circ}}$.Well-known antioxidants include number of enzymes and other substances such as vitamin $C$, vitamin $E$, and beta carotene (which is converted to vitamin $A$ ) that are capable of counteracting the damaging effects of oxidation. ${ }^{r \&}$ Antioxidants are also commonly added to food products like vegetable oils and prepared foods to prevent or delay their deterioration from the action of air. ${ }^{r+}$ Al-Jaff and coworkers found a significant role of oxidative stress in patients with $A A$, and that nutrient antioxidants modulate tissue antioxidant status and subsequently the clinical pictures of the disease. $^{\text {rv }}$

The present study was designed to correlate between the duration of attack of AA and their response to antioxidant vitamins treatment.

\section{Subjects and methods}

Subjects: The study group comprised of total of $r$. patients with AA with age range $I V-\varepsilon V$ years, $r$ r male with $\vee$ female. The duration of disease ranged from ( $r$. days $-1 \wedge$ years). They were divided into $r$ groups according to the duration of disease attack: group ' (less than one year), 9 patients; group $r$ ( $1-r$ years), 1. patients; and group $r$ (more than $r$ years). I'patients. All groups received treatment schedule including: 
A- A combination of antioxidants [vitamin A tablet ( $0 \ldots$ I.U/day), vitamin $E$ tablet $(1 \cdots \mathrm{mg} /$ day) and vitamin $\mathrm{C}$ tablet $(0 .$. $\mathrm{mg} /$ day)] for two months.

B- Traditional treatment which includes [corticosteroids, (spironolactone), local irritant, phototherapy and tonics].

Patients involved in this study were nonsmokers, non-alcoholics and free from apparent other diseases and were under dermatologist supervision for the determination of severity of disease and its progression.

Method: Heparinized venous blood samples were collected from patients before and after 1 and $r$ months of treatment for the measurement of MDA and GSH in lymphocytes and erythrocytes using modified method of Stocks and Dormandy as described by Gilbert et al , ${ }^{\left(r \lambda,{ }^{q}\right)}$; and the method of Godin et al ${ }^{(*)}$ respectively. Peroxidative challenge was induced by the addition of $1 . \cdot \mathrm{ml}$ of $\mathrm{V} .{ }^{\circ} \mathrm{mM}$ $\mathrm{H}_{r} \mathrm{O}_{r}$ in isotonic saline azide solution (Final $\mathrm{H}_{r} \mathrm{O}_{r}$ concentrations ${ }^{\circ} .0 \mathrm{mM}$ ) . Basal level of MDA was obtained without addition of $\mathrm{H}_{r} \mathrm{O}_{r}$, i.e. $\mathrm{H}_{r} \mathrm{O}_{r}$ concentration was zero. Following $r$. min. incubation at $\mathrm{rv}^{\circ} \mathrm{C}$, the reaction was terminated by addition of $1 . \cdot \mathrm{ml} r \wedge \%$ (TCA. IM sodium arsenite). The mixture was centrifuged, and $r . \cdot \mathrm{ml}$ of supernatant was combined with.$\circ \mathrm{ml}$ distilled water, $1 . \cdot \mathrm{ml}$ of . $.0 \%$ TBA in. $.0 \mathrm{M}$ sodium hydroxide. Color development was achieved by boiling for 10 min. The tubes were cooled under tap water and the extent of MDA production was estimated from the absorbences at orr and sor $\mathrm{nm}{ }^{r \wedge}$, rq. In addition, TAS in lymphocytes samples was determined using Randox TAS kit.

Assay principle: ABTS $®\left(r, Y--\right.$ Azino-di- $\left[r^{r}-\right.$ ethylbenzthiazoline sulphonate]) is incubated with a peroxidase (metmyoglobin) and $\mathrm{H}_{\mathrm{r}} \mathrm{O}_{r}$ to produce the $A B T S \&$ radical. This has a relatively stable blue-green color, which is measured at $7 . . \mathrm{nm}$. Antioxidant in the added sample causes suppression of this color production to a degree which is proportional to their concentration ${ }^{r}$.
$\mathrm{HX}-\mathrm{Fe} \mathrm{III}+\mathrm{H}_{\mathrm{r}} \mathrm{O}_{\mathrm{r}} \rightarrow \mathrm{X}-\left[\mathrm{Fe}^{\mathrm{IV}}\right]+\mathrm{H}_{\mathrm{r}} \mathrm{O}$

$\mathrm{ABTS}^{\circledR}+\mathrm{X}-[\mathrm{Fe} \mathrm{IV}=\cdot] \rightarrow \mathrm{ABST}^{+}+\mathrm{HX}-\mathrm{F}^{\mathrm{III}}$

The statistical significance of mean change of an outcome parameter after treatment (treatment effect) was assessed by paired ttest. The statistical significance of the difference in mean between more than $r$ study groups was tested by ANOVA test.

\section{Results \\ Oxidative Stress Markers in Lymphocyte and Erythrocyte}

Table, showed that treatment with antioxidants of AA patients resulted in significant reduction in basal lymphocyte MDA level in all groups in comparison to their base line values; however, greater and significant reduction in MDA levels were achieved after $r$ months of treatment in comparison to their level after 1 month $(p<\cdot .0)$. On the other hand, lymphocytes from patients with AA expressed great sensitivity to endogenous oxidants represented by great and significant elevation in their MDA level following challenge with $\mathrm{V}_{.} . \% \mathrm{H}_{\mathrm{r}} \mathrm{O}_{r}$ when compared with basal MDA level (table $), p<. . \cdots$. Treatment with antioxidant vitamins (A,E and C) significantly improves lymphocyte ability to counteract oxidative stress as shown by great and significant decrease in MDA level $(p<\cdot .0)$. In addition, highly significant reduction in MDA levels was achieved after $r$ months of treatment when compared with corresponding levels achieved after 1 month $(p$ $\left.<\cdot{ }^{\circ}\right)$. These decrements in basal and $\mathrm{H}_{r} \mathrm{O}_{r}$ challenged MDA levels were correlated with improvements of defense ability of lymphocytes against oxidants as measured by total antioxidant status (TAS) kit as shown in table $r$ In this context, treatment with antioxidant vitamins resulted in significant elevation of TAS after 1 and $r$ months in comparison with their baseline level $\left(p<\cdot .{ }^{\circ}\right)$; however ,highly significant improvements were achieved after $r$ months than those achieved after 1 month $(p<\cdot .0)$. Interestingly, there is no significant difference in lymphocyte levels of TAS, basal and $\mathrm{H}_{r} \mathrm{O}_{r}$ challenged MDA among all groups $(p>\cdot . \bullet$, by ANOVA). 
Table $r$ showed that treatment with antioxidant vitamins $(A, E, C)$ also resulted in significant reduction in basal erythrocyte MDA level in all groups in comparison to their baseline values $(p<\cdot .0)$.

The greater and significant reduction in MDA levels were achieved after $r$ months of treatment in comparison to those after ' month $(p<\cdot \cdot 0)$. Erythrocytes from patients with AA expressed great sensitivity to endogenous oxidants represented by great and significant elevation in their MDA levels following challenge with $\mathrm{V}^{\circ} . \% \mathrm{H}_{r} \mathrm{O}_{r}$ when compared with basal MDA levels $\mathrm{p}<\cdot . \cdots$. (tabler), Treatment with antioxidant vitamins significantly improves erythrocyte ability to counteract oxidant effect as shown by great and significant decrease in MDA levels $(p<\cdot .0)$. In addition, highly significant reduction in MDA levels was achieved after $r$ months of treatment when compared with corresponding levels achieved after I month $(p<\cdot .0)$. Importantly, there is no significant difference in erythrocyte basal and $\mathrm{H}_{r} \mathrm{O}_{r}$ challenged MDA levels in all groups $(p>\cdot . \circ$, by ANOVA).

\section{Antioxidant Marker (GSH) in Lymphocytes and Erythrocytes}

Table $\varepsilon$ and table $\bullet$ showed the effect of treatment of AA patients with antioxidant vitamins ( $A, E$ and $C$ ) on $G S H$ levels in lymphocytes and erythrocytes, respectively. Antioxidants significantly elevated the levels of GSH in a time dependant manner in both lymphocytes and erythrocytes in comparison with baseline levels $(p<\cdot .0)$. However, after $r$ months of treatment, the levels of GSH were significantly higher than those after I month treatment in both lymphocytes and erythrocytes samples $(p<\cdot . \cdot 0)$. Meanwhile, no significant difference in the effect of antioxidant was observed among patient group ( $p>\cdot . \bullet$, by ANOVA) in both lymphocytes and erythrocytes samples.

Table (1)

Lymphocyte MDA (OD/mgrotein)

Basal level

After $\int .5 \% \mathrm{H}_{2} \mathrm{U}_{2}$ challenge

\begin{tabular}{|c|c|c|c|c|c|c|}
\hline & Bustiute & EI 1 InUILlh & 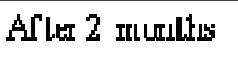 & Batetirut & 1 Irturlhi & 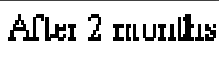 \\
\hline $\begin{array}{l}\text { Group } 1 \\
(\mathrm{r}=9)\end{array}$ & $0.16 \pm 0.02^{\mathrm{a}}$ & $0.13 \pm 0.04^{b}$ & $0.04 \pm 0.01^{c}$ & $0.89 \pm 0.12^{\mathrm{a} \dagger}$ & $0.54 \pm 0.16^{\mathrm{b} \dagger}$ & $0.48 \pm 0.12^{\mathrm{c}}$ \\
\hline $\begin{array}{l}\text { Group } 2 \\
(\mathrm{n}=10)\end{array}$ & $0.14 \pm 0.04^{a}$ & $0.09 \pm 0.03^{b}$ & $0.05 \pm 0.02^{c}$ & $0.85 \pm 0.11^{\text {af }}$ & $0.63 \pm 0.13^{b \dagger}$ & $0.45 \pm 0.07$ \\
\hline$(\mathrm{n}=11)$ & $0.14 \pm 0.03^{a}$ & $0.09 \pm 0.04^{b}$ & $0.05 \pm 0.02^{c}$ & $0.82 \pm 0.23^{\mathrm{a} T}$ & $0.64 \pm 0.26^{\mathrm{b} T}$ & $0.48 \pm 0.09$ \\
\hline ANOWA & $\mathrm{NS}$ & $\mathrm{MS}$ & $\mathrm{MS}$ & $\mathrm{NS}$ & NS & $\mathrm{NS}$ \\
\hline
\end{tabular}

Data are expressed as mean $\pm \mathrm{SD}$.

$\mathrm{n}=$ number of patients.

Non-identical superscripts $(\mathrm{a}, \mathrm{b}, \mathrm{c})$ among different time intervals considered significantly different $(\mathrm{P}<\cdot . \bullet)$.

${ }^{\dagger} \mathrm{P}<\cdot . .+$ with respect to corresponding time of the basal MDA levels.

OD: Optical density 
Table r: Lymphocyte TAS (micro mol/mg protein)

\begin{tabular}{|c|c|c|c|c|}
\hline \multicolumn{5}{|c|}{ Basal level } \\
\hline & & after I month & after $r$ months & \\
\hline Group 1 & $\theta^{0 \top \pm} \pm .19^{\mathrm{a}}$ & $(n=9)$ & $\because .9 Y \pm \cdot . Y^{b}$ & $1 . r q \pm \cdot . r^{c}$ \\
\hline Groupr & $\because \diamond \wedge \pm \cdot .1 \mu^{a}$ & $(n=1 \cdot)$ & $\because 9 \wedge \pm \cdot .1 \vee^{b}$ & $1 . r r \pm \cdot . r \Sigma^{c}$ \\
\hline Groupr & $\cdot \because v \pm \cdot .1 r^{a}$ & $(n=11)$ & $1 . \cdots \pm \cdot r^{b}$ & $1.0 v \pm \cdot . r \Sigma^{c}$ \\
\hline ANOVA & NS & & NS & NS \\
\hline
\end{tabular}

Data expressed as mean $\pm \mathrm{SD}$

$\mathrm{N}=$ number of patients

Non-identical superscripts (a,b,c)among different time intervals considered significantly different $(p<\cdot .0)$

Table (3)

Erythrocyte MDA (OD/g Hb)

\begin{tabular}{|c|c|c|c|c|c|c|c|}
\hline & \multicolumn{3}{|c|}{ B asal leve1 } & \multicolumn{4}{|c|}{ After $7.5 \% \mathrm{H}_{2} \mathrm{O}_{2}$ challenge } \\
\hline & Baseline & fter 1 month & After 2 months & B aseline & After & r 1 month & After 2 months \\
\hline \multirow{3}{*}{$\begin{array}{l}\text { Group } 1 \\
(\mathrm{tr}=9) \\
\text { Group } 2 \\
(\mathrm{Ir}=10) \\
\text { Group } 3 \\
(\mathrm{tr}=11)\end{array}$} & $0.85 \pm 0.10^{2}$ & $0.31 \pm 0.06^{b}$ & $0.17 \pm 0.04^{c}$ & \multicolumn{2}{|c|}{$7.84 \pm 0.12$ at } & $5.58 \pm 0.71 \mathrm{bt}$ & $3.15 \pm 0.99 \mathrm{ct}$ \\
\hline & $0.90 \perp 0.09^{\circ}$ & $0.30 \perp 0.05^{b}$ & $0.17 \perp 0.04$ & \multicolumn{2}{|c|}{$8.17 \perp 0.11$} & $5.31 \perp 0.74^{b t}$ & $3.14 \perp 0.89 \mathrm{ct}$ \\
\hline & $0.91 \pm 0.08^{2}$ & $0.30 \pm 0.08^{b}$ & $0.16 \pm 0.05^{c}$ & \multicolumn{2}{|c|}{$7.93 \pm 0.23 \mathrm{at}$} & $5.27 \pm 1.69^{\mathrm{bt}}$ & $2.97 \pm 1.18^{\mathrm{c}}$ \\
\hline AWOW A & NS & WS & NS & \multicolumn{2}{|c|}{ NS } & WS & NS \\
\hline
\end{tabular}

Data are expressed as mean \pm SD

$\mathrm{n}=$ number of patients.

Non-identical superscripts (a, b, c) among different time intervals considered significantly different $(P<\cdot . .0)$.

Table (4)

Lymphocyte 년

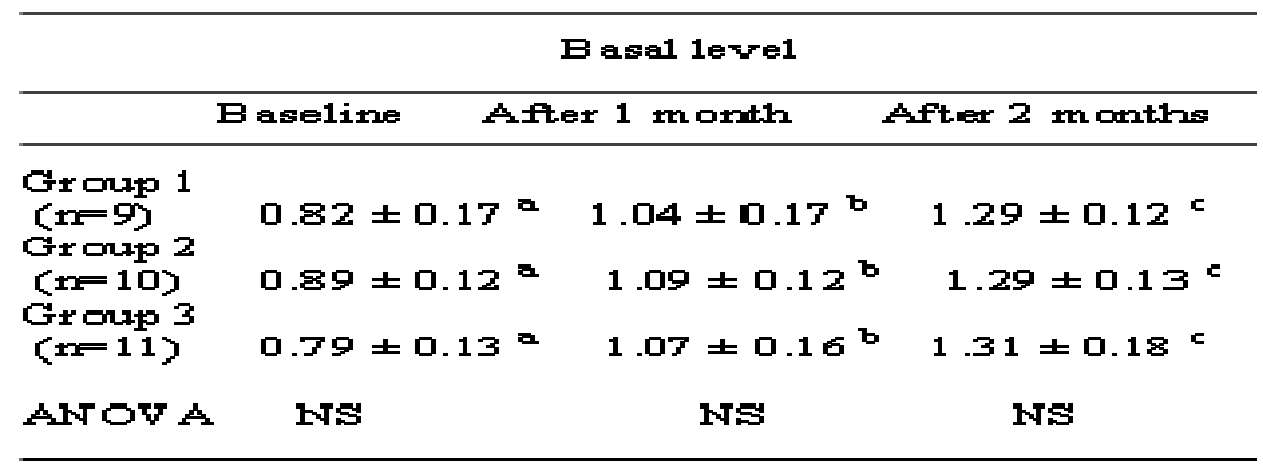

Data are expressed as mean $\pm \mathrm{SD}$.

$\mathrm{n}=$ number of patients.

Non-identical superscripts $(a, b, c)$ among different time intervals considered significantly different $(P<\cdot .0)$. 
Table : Erythrocyte GSH (OD/g Hb)

\begin{tabular}{|c|c|c|c|}
\hline & & Basal level & \\
\hline & Baseline & after ' month & after rmonths \\
\hline $\begin{array}{l}\text { Gruop }) \\
(n=9)\end{array}$ & $1 \cdot . \wedge v \pm r . \wedge \cdot{ }^{a}$ & $10.1 Y \pm Y . Y q^{b}$ & $r \cdot . \cdot \Delta \pm r .1 r^{c}$ \\
\hline $\begin{array}{l}\text { Groupr } \\
(n=1 .)\end{array}$ & $1 . .0 r \pm r .1 v^{a}$ & 10. & $r \cdot . v 1 \pm 1.90^{c}$ \\
\hline $\begin{array}{l}\text { Groupr } \\
(n=11)\end{array}$ & $1 \cdot .9 v \pm \mathbf{r} .00^{a}$ & $18.7 \leqslant \pm r .9^{b}$ & $r \cdot . r q \pm 1.00 c$ \\
\hline ANOVA & NS & NS & NS \\
\hline
\end{tabular}

Data are expressed as mean \pm SD

$n=$ number of patients

Non-identical superscripts $(a, b, c)$ among different time intervals considered significantly different $(p<\cdot . \cdot 0)$.

\section{Discussion}

The management of $A A$ is obviously not restricted to the prescription of a treatment including hair growth since the exact cause of $A A$ is unknown till now ', ' '; and this requires through exploration (history of hair loss, treatments and concomitant pathologies), detailed clinical examination of the integument and palpation of the thyroid .However, there is no permanent cure for $A A$ and there is no universally proven therapy for inducing remission.

All the current modalities used for the management of AA are more effective in those with milder forms of disease but much less effective in people with extensive hair loss ${ }^{17}$.Various therapies of several groups with different mechanism of actions were tried for the management of AA including (corticosteroids, cyclosporine, anthralin, dithranol, dinitrochlorobenzene, squaric acid dibutyl ester, minoxidil, cytokines, gene therapy, and melatonin). ${ }^{r}$

In the past few years, several studies have presented several lines of evidence for the involvement of reactive oxygen species (ROS) in the pathogenesis of $A A$ as well as other disorders. Al-Jaff and co-workers investigated the role of oxidative stress in patients with $A A$, and the effect of nutrient antioxidants on tissue antioxidant status and clinical pictures of disease. $^{r v}$

In this study, patients with $A A$ showed a significant increase in basal MDA levels and a decrease in lymphocyte and Erythrocyte GSH

r..人 Mosul College of Pharmacy levels with a decrease lymphocyte TAS levels. This picture was associated with increased susceptibility to oxidative stress manifested by increased lymphocytes and erythrocytes MDA levels in response to in vitro challenge with $V_{.} . \% \mathrm{H}_{r} \mathrm{O}_{r}{ }^{r}, r r$ Therapy with nutrient antioxidants in these patients significantly improved tissue antioxidant status and was associated with good clinical response in their hair growth. The result of Al-jaff et.al study clearly demonstrated that the ability of antioxidants to correct most of the observed alterations in antioxidant defense mechanisms in patients with AA was obvious regardless of whether traditional treatment was given concurrently with antioxidants or being previously administered to patients. This finding ,together with the fact that comparable correction was also observed when vitamins antioxidants were given as the sole therapy (i.e .without traditional treatment) to patients ,further supports the hypothesis the beneficial effects are more likely attributed to the antioxidant therapy (vitamin, melantonin) than to the traditional therapy, and that the latter has a little role in this regard .However, it should be mentioned that the presence of concomitant traditional treatment with vitamins did further improve lymphocyte GSH levels compared to vitamins alone by an, as yet, un explained mechanism ${ }^{r r}$. However, since these vitamins are part of the body 's defense mechanism against ROS, the addition of these nutrient antioxidants to corticosteroids 
attenuated the negative effects of oxidative stress on immune system and decreased the need for high dose of immune suppressants (corticosteroids); thereby decreased the unwanted side effects associated with the prolonged use of the high dose. ${ }^{r r}$

Traditional treatment (especially prednisolone) affects the immune by decreasing the immune complex deposition, while the nutrient antioxidants may act by inhibiting the negative effect of ROS on immune system, thus increasing rate of hair growth. The mechanisms by which these vitamins protect the immune system could be through either a direct and /or an in direct effect. Vitamin A or retinol is essential for innate (non-specific) immunity. Semba noted that vitamin $A$ is an immune enhancer that has been shown to increase lymphocyte clonal proliferation responses to antigens and mitogen, increase antibody response to T-cell dependant antigens, inhibit programmed cell death (apoptosis), and restore the health and the function of damaged mucous membranes.

rs Supplementation with vitamin E leads to reinforce the immune system's resistance to any infectious disease ${ }^{\left(r^{\circ}\right)}$.The indirect effect may be through increasing the vitamin $A$ level in body since high dose of corticosterone resulted in a rapid loss of vitamin $A$ from plasma, liver, adrenals and thymus. vitamin $\mathrm{C}$ is an immunostimulatory, anti-inflammatory, anti-allergic agent. ${ }^{\text {" }}$ Anderson ${ }^{\text {TV }}$ also noted that many experiments showed vitamin $C$ to enhance $T$ lymphocyte reactivity to mitogens in humans and animals. The indirect effect is that vitamin $C$ is a powerful antioxidant that protects against damaging effect of phagocytes derived radicals to patients using corticosterone for periods longer than $r$ weeks should take vitamin C supplement to counteracts the depleting effect of corticosterone since the steroidal antiinflammatory drugs causes increased loss of vitamin $C$ through the urine. "Vitamins $E$ and $C$ act synergistically to protect membranes from lipid auto-oxidation and play a key role in protecting phagocytes from damage by selfgenerated free radicals, since immune cells have a high percentage of easily oxidized fatty acids in their membranes. ${ }^{\text {rV }}$ Phagocyte membrane auto-oxidation is a major immune problem, since macrophages are necessary to antigenically activate T lymphocytes. ${ }^{r V}$

These effects suggest important role of nutrient antioxidants in protecting the body (e.g. immune system) from oxidative damage and may influence the severity of $\left.A A^{r Y} r\right)$. Accordingly, they recommended the use of nutrient antioxidants (Vitamin A, C and E) with traditional treatment like corticosteroids, local irritant, phototherapy and tonics in the management of $A A$.

This study correlates between the duration of disease attack and response to antioxidant treatment. Patchy AA of less than one year duration is more likely to respond to traditional treatment with a success rate estimated at $v_{0 \%}$. AA that has persisted, with or without traditional treatment for more than two years is likely to respond to further treatment. Only about $\varepsilon . \%$ of people with long term hair loss respond to traditional treatment. ${ }^{r}$ "The result of this study revealed that no significant differences in the response (oxidative stress markers, body antioxidant defense mechanism ,and rate of hair growth) of the three study groups to antioxidant vitamins therapy and this could be due to enhancement of lymphocytes and erythrocytes GSH contents and lymphocytes total antioxidant status to levels that successfully attenuate the increased oxidative insult together with direct and /or indirect scavenging activity of these vitamins, a fact that may in turn lead to the inhibition of protein oxidation and decrease the utilization and damage of GSH and proteins by free radicals to same level in all study groups so that giving the same clinical response.

In conclusion the result of this study revealed that treatment with antioxidant vitamins significantly improves the clinical picture of AA regardless of duration of disease.

\section{References}

1. Thomas P. Habif MD "Clinical Dermatology" A color guide to diagnosis and therapy. $\varepsilon^{\text {th }}$ edition, Mobsy, Philadelphia, Pennsylvania. $r . . \varepsilon$; chapter $r \leqslant$ : 100 .

r. Champio-RH; Burton-JL; Burns-DA; Breathnach Eds "Textbook of dermatology ". $7^{\text {th }}$ edition, Blackwell science, England. r..r;: :rq.r-rqr人. 
r. Fauci-A.S., Braunwald - E ,Isselbacher -K.J " principles of internal medicine" Eds. $\varepsilon^{\text {th }}$ edition ,MC Graw-Hill, New York. Y.. I:r. r. r) $\leqslant$.

ะ. Barahamani N;De Andrade M, Slusser J; Zhang Q; Duvic M. Interleukin-) receptor antagonist allele $r$ and familial alopecia areata.J-Invest-Dermatol. $r \ldots r ; 1) \wedge(r):$ ז _ $\mathrm{v}$.

๑. Tazi-Ahini R; cork MJ; Gawkrodger DJ ;Birch MP; wengraf D;MC Donagh AJ; Messenger AG. Role of the autoimmune regulator (AIRE) gene in alopecia areata: strong association of a potentially functional AIRE polymorphism with alopecia universalis.

7. Muller-HK; Rook-AJ; Kubba-R. Immunohistology and autoantibody studies in alopecia areata. Br J Dermatol. $19 \wedge \cdot ; 1 \cdot r$ : 7. 9-10.

$\checkmark$. Hordinsky-MK. Alopecia areata in: Olsen $E A$, ed. Disorder of hair growth.New York:Mc Graw- litill. 199 : : $190_{-}$r r .

^. Hoffmann-R; Happle-R. Alopecia areata. Part I Clinical aspects, etiology, pathogenesis. Hautarzt. 1999; $0 .(r)$ :WrYr. ए.

१. Mc Donagh-AJ; Messenger -AG. The etiology and pathogenesis of alopecia areata.J-Dermatol-Sci. 199६;〉 Suppl : S iro-ro.

1.Sharma-VK; Sialy-R; Kumar-B; Guptas. Evaluation of thyroid function in north Indians with alopecia Areata: Response ti I.V injection of $1 \cdots$ migrograms thyrotropin releasing hormone (TRH) .J Dermatol. 1999

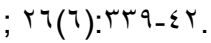

11.Puavilai-S; Puavilai-G; CharuwichitratanaS; Sakuntabhai; Sriprachya Anunt-S. Prevalence of thyroid diseases in patients with alopecia areata.Int-J-Dermatol. 199 ; rr(9): 7 rr-r.

Ir.Shong-YK; Kim-JA. Vitiligo on autoimmune thyroid disease. Thyroidology. $1991 ; r(r): \wedge 9$ 9).

1r. Majumder-PP; Nordlund -JJ; NATH-SK. Pattern of familial aggregation of vitiligo $.1994 ; 1 r 9(\wedge): 99 \leq-\wedge$.

I . Werth-VP; white -WL; Sanchez-MR; Franks-AG. Incidence of alopecia areata in lupus erythromatous.ArchDermatol. $199 r ; \mid r \wedge(r)$ : rฯง-V।.
10.Kossards. lupus panniculitis clinically simulating alopecia areata. Australas JDermatol. $r \ldots r ; \varepsilon r(r): r r)-r$.

17. Bennett-JC; Plum-F; Eds. "Text book of Medicine ". Y. th edition ,W.B. Saunders company.London. 1997:Yr10-rr।V.

Iv.Tan E; Tay Y.K; Goh CL; Chin Giam Y. The pattern and profile of alopecia areata in aingapore- a study of $r / 9$ Asian .Int $J$

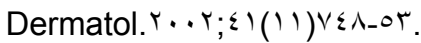

1^. Janninger-CK. Alopecia areata.Cutis. 1994 $\mathrm{Nov} ; 0 \cdot(0): r \leqslant \vee-9$.

19. Gopia AK, et al. Oral cyclosporine for treatment of alopecia areata,A clinical and immunohistochemical analysis. J AM Acad Dermatol. $199 \cdot, r r: r \leqslant r$.

$r \cdot$ Assouly P. Alopecia areata: update on therapy. Ann-Dermatol Venereol. r..r;। rq(० pt r):^r 1- .

$r$. Jennifer Bahney. Three steps to healthy long hair. Longhair lovers.com

r. Vlaszdole, Huile. Flaxseed oil and other life giving oils. . . . ¿.Shirleys wellness café.com.

$r$. Alopecia areata alternative treatment.

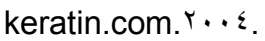

rะ.Halliwell B; Gutteridge JM.," Free radicals in biology and medicine". ${ }^{\text {nd }}$ ed. Oxford: Clarendon Press, 1919.

ro. Halliwell B; Gutteridge JC. The definition and measurement of antioxidants in biological systems. Free Radic Biol Med $.1990 ; 111$ ro-7.

$r$. Bradley. superpopular food, $r \ldots v$ (http: www.natural productsmarketplace.com)

$r \vee$.Al-Jaff A; et al. The role of oxidative stress in alopecia areata. Iraqi Journal of Pharmacy. ... 1; volume 1, No . .: P r $\varepsilon_{-} \leqslant 0$

r^.Stocks-J and Dormandy -T.L. The autooxidation of human red blood cell lipids induced hydrogen peroxide. Brit-JHematol. 19v1; $r .: 90-111$.

r१. Gilbert-HS; Stump-DD and Roth-EF. A method to correct for errors caused by generation of interfering compounds during erythrocyte lipid peroxidation. Anal-

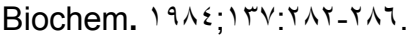

r. Godin-DV; Wohaib-SA; Garnett-ME. And Goumeiouk-AD. Antioxidant enzyme alterations in experimental and clinical diabetes. Mole And Cellular-Bioch. 19^^; AE:rrT-rTl. 
r. Miller NJ; Rice-Evance C; Duvies MJ; Gopinathan V. and Milner A. Total antioxidant status by colometric method.

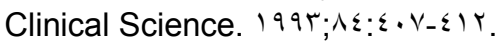

r.Al-Jaff A; Hammadi S; Wohaieb $S$. Evaluation of oxidative stress indicators in lymphocyte of patients with alopecia areata. Doctoral thesis. University of Bghdad. ${ }^{\prime} . .0$.

$r$ r.Al-Jaff $A$ et al. The ability of nutrient antioxidants to influence oxidative stress and lower the dose of prednisolone in patients with alopecia areata. Iraqi journal of pharmaceutical science. Y.. 7 .vol 10(1): 17.
rร.Semba R.D. Vitamin A, immunity and infection. Clin Infe. Dis 19:^^৭-৭৭.

ro.Atkins R.Vita - nutrient solution. NYC: Simon \& Schuster. 199^: $\leqslant$.

זч. Anderson, R, " The immunomodulatory, antiinflammatory and anti-allergic properties of ascorbate " in advances in nutritional research, H. Draper, ed. NYC: Plenum

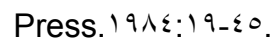

$r v$.Del Rio, M. et al. Improvement by several antioxidants of macrophage function in vitro. Life Sci. $199 \wedge ; 7 r: \wedge \vee 1-\wedge 1$. 